\title{
PERAN BIMBINGAN DAN KONSELING DALAM PENYELENGGARAAN PENDIDIKAN INKLUSIF
}

\author{
A. Hari Witono \\ Universitas Mataram, Mataram, Indonesia \\ E-mail: hariwotono.fkip@unram.ac.id
}

\begin{tabular}{|c|c|}
\hline ARTICLE INFO & ABSTRACT \\
\hline $\begin{array}{l}\text { Article history } \\
\text { Received: August 2, } 2020 \\
\text { Revised: August 3, 2020 } \\
\text { Accepted: August 12, } 2020 \\
\text { Keywords: } \\
\text { counseling guidance, inclusive } \\
\text { education, child psychology }\end{array}$ & $\begin{array}{l}\text { Guidance and Counseling (BK) has become a unity in the overall education } \\
\text { system. It can be seen from formal education, non-formal and informal } \\
\text { education as well. It is also included in the inclusive education model, the } \\
\text { service has become a unity and strength in the education system, namely } \\
\text { school management-administration and teaching learning process. The } \\
\text { three educational services, can be a strength in services to achieve the } \\
\text { educational goals. The implementation of BK for inclusive education has a } \\
\text { very strategic role for students, namely services for (1) Orientation, (2) } \\
\text { Information, (3) Data collection (appraisal), (4) Consultation, (5) } \\
\text { (Counseling), and Referral. }\end{array}$ \\
\hline
\end{tabular}

\section{A. PENDAhULUAN}

Bimbingan dan Konseling (BK) telah menjadi satu kesatuan dalam sistem Pendidikan secara menyeluruh. Mulai dari Pendidikan formal, Non formal dan bahkan dalam Pendidikan informal sekali pun. Meskipun dalam sistem Pendidikan yang disebut terakhir ini di Indonesia secara tersetruktur belum tersentuh dengan bimbingan dan konseling sebagaimana di dalam sistem Pendidikan formal pada umumnya. Keberadaannya BK, terutama di sekolah formal, termasuk dalam penyelenggaraan Pendidikan inklusif menjadi satu kesatuan utuh dengan kekuatan lainnya, yakni managemen-administrasi sekolah dan proses belajar mengajar yang diselenggarakan oleh guru bidang studi (Depdiknas, 2008: 25). Dengan demikian tujuan bimbingan konseling pun integral dengan tujuan Pendidikan pada umumnya, yaitu Memenuhi amanat Undang-Undang Dasar 1945 khususnya Ps. 32 ayat 1 yang berbunyi 'setiap warga negara negara berhak mendapat pendidikan', dan ayat 2 yang berbunyi 'setiap warga negara wajib mengikuti pendidikan dasar dan pemerintah wajib membiayainya'. UU no. 20/2003 tentang Sistem Pendidikan Nasional, khususnya Ps. 5 ayat 1 yang berbunyi 'setiap warga negara mempunyai hak yang sama untuk memperoleh pendidikan yang bermutu'. UU No. 23/2002 tentang Perlindungan Anak, khususnya Ps. 51 yang berbunyi 'anak yang menyandang cacat fisik dan/atau mental diberikana kesempatan yang sama dan aksesibilitas untuk memperoleh pendidikan biasa dan pendidikan luar biasa. 
Kebaradaan BK yang berada pada system pendidikan inklusif berpadu dalam system dan menjadi model penyelenggaraan pendidikan formal yang menggabungkan antara anak berkebutuhan khusus dengan anak normal dalam proses kegiatan pembelajaran seperti biasa. UNESCO dalam Lay Kekeh Marthan (2007: 143) mengemukakan bahwa: "inclusive education is a developmental approach seeking to address the learning needs of all children, youth and adults with a specific focus on those who are vulnerable to marginalization and exclusion". Dengan demikian, dapat diartikan bahwa Bimbingan dan konseling dalam pendidikan inklusif adalah sebuah pendekatan integrative yang berhubungan dengan pengembangan yang ditujukan untuk memenuhi kebutuhan belajar seluruh anak tanpa ada perbedaan dan pemisahan. Dengan kata lain, dalam pendidikan inklusif berusaha memberikan hak yang sama kepada setiap peserta didik untuk mengembangkan potensinya. Setiap peserta didik yang memiliki kelainan fisik, emosional, mental, dan sosial atau berkebutuhan khusus berhak mengikuti pendidikan secara inklusi pada satuan pendidikan tertentu sesuai dengan kebutuhan dan kemampuannya.

\section{B. KAJIAN TEORI}

\section{Kedudukan Bimbingan dan Konseling secara formal dan dalam setting pendidikan formal, termasuk dalam Pendidikan inklusif}

Secara formal kedudukan bimbingan dan konseling ada dalam Sistem Pendidikan di Indonesia, antara lain, (a) UU No. 2 tahun 1989 bab I pasal 1 ayat 1 yang menyatakan bahwa: "Pendidikan adalah usaha sadar menyiapkan peserta didik melalui bimbingan dan atau latihan bagi peranannya di masa yang akan datang"; (b). $\quad$ PP No. 28 untuk SD dan PP No. 29 untuk SMP dan SMA tahun 1990 Bab X pasal 25 ayat 1 yang dinyatakan "Bimbingan adalah bantuan peserta didik untuk memahami diri, mengenal lingkungan dan merencanakan masa depan” "Bimbingan dilaksanakan oleh guru pembimbing” (b). UU No. 20 tahun 2003 bab I pasal 1 ayat 6 "Pendidik adalah tenaga kependidikan yang berkualifikasi sebagai guru, dosen, dan konselor, widyaiswara, pamong belajar, fasilitator dan sebutan lain sesuai dengan kekhususannya serta berpartisipasi dalam menyelenggarakan pendidikan”.

Memperhatikan dasar yuridis tersebut diatas, maka bimbingan konseling di sekolahsekolah, terlebih di model Pendidikan inklusif keberadaannya sangat diperlukan, dan bahkan telah menjadi suatu keharusan yang harus dilaksanakan oleh pihak-pihak yang terkait dengan system Pendidikan di masyarakat.

\section{Asas dan prinsip BK dalam pendidikan iklusif}


Keberhasilan bimbingan dan konseling di dalam setting Pendidikan inklusif sangat ditentukan oleh diwujudkannya asas-asas bimbingan dan konseling yang melandasinya. Asasasas yang berkenaan dengan praktik atau pekerjaan bimbingan dan konseling sama dengan azas BK pada Pendidikan formal pada umumnya, Prayitno, dan Erman Amti (2016:27) menegaskan azas dimaksud sebagai berikut: (1) Rahasia, yaitu menuntut dirahasiakannya segenap data dan keterangan tentang peserta didik (klien) yang menjadi sasaran layanan, termasuk anak yang berkebutuhan khusus tentang data atau keterangan yang tidak boleh dan tidak layak diketahui oleh orang lain. Dalam hal ini guru pembimbing (konselor sekolah) berkewajiban penuh memelihara dan menjaga semua data dan keterangan itu sehingga kerahasiaan itu benar-benar terjamin; (2). Sukarela, yaitu mengehendaki adanya kesukaan dan kerelaan peserta didik mengikuti menjalani layanan/ kegiatan yang diperlukan baginya. Guru pembimbing berkewajiban membina dan mengembangkan kesukarelaan tersebut;(3) Terbuka, yaitu menghendaki peseta didik yang menjadi sasaran layanan/ kegiatan bersifat terbuka dan tidak berpura-pura, baik di dalam memberikan keterangan tentang dirinya sendiri maupun dalam menerima berbagai informasi dan materi dari luar yang berguna bagi pengembangan dirinya. Guru pembimbing berkewajiban mengembangkan keterbukaan peseta didik (klien) baik anak yang noral mapun yang memiliki kebutuhan khusus (disabilitas) (Hidayati et al., 2020). Agar peserta didik dapat terbuka, guru pembimbing terlebih dahulu harus bersikap terbuka dan tidak berpura-pura; (4) Kegiatan, yaitu menghendaki agar peserta didik (klien) yang menjadi sasaran layanan berpartisispasi secara aktif di dalam penyelenggaraan layanan/kegiatan bimbingan. Guru pembimbing perlu mendororng peserta didik untuk aktif dalam setiap layanan/kegiatan bimbingan dan konseling yang diperuntukkan baginya;(5) Mandiri, yaitu menunjuk pada tujuan umum bimbingan dan konseling, yakni peserta didik (klien) sebagai sasaran layanan bimbingan dan konseling diharapkan menjadi individu-individu yang mandiri dengan ciri-ciri mengengal dan menerima diri sendiri dan lingkungannya, maupun mengambil keputusan, mengarahkan serta mewujudkan diri sendiri;(6) Kekinian, yaitu menghendaki agar objek sasaran layanan bimbingan dan konseling ialah permasalahan peseta didik (klien) dalam kondisi sekarang. Layanan yang berkenaan dengan "masa depan atau kondisi masa lampau pun" dilihat dampak dan/atau kaitannya dengan kondisi yang ada dan apa yang diperbuat sekarang (Maulyda, Nurmawanti, et al., 2020); (7) Dinamis, yaitu asas bimbingan dan konseling yang menghendaki agar isi layanan terhadap sasaran layanan (klien) yang sama kehendaknya selalu bergerak maju, tidak monoton, dan terus berkembang serta berkelanjutan sesuai dengan kebutuhan dan tahap perkembangan dari waktu ke waktu; (8) Terpadu, yaitu asas bimbingan dan konseling di sekolah 
inklusif menghendaki agar berbagai layanan dan kegiatan bimbingan dan konseling, baik yang dilakukan oleh guru pembimbing maupun pihak lain, saling menunjang, harmonis dan terpadu. Kerjasama antara guru pembimbing dan pihak-pihak yang berperan dalam penyelenggaraan pelayanan bimbingan dan konseling perlu terus dikembangkan. Koordinasi segenap layanan/kegiatan bimbingan dan konseling itu harus dilaksanakan dengan sebaik-baiknya; (9) Harmonis, yaitu menghendaki agar segenap layanan dan kegiatan bimbingan dan konseling didasarkan pada nilai dan norma yang ada, tidak boleh bertentangan dengan nilai dan norma yang ada, yaitu nilai dan norma agama, hukum dan peraturan, adat istiadat, ilmu pengetahuan, dan kebiasaan yang berlaku. Layanan dan kegiatan bimbingan dan konseling harus dapat meningkatkan kemmapuan peserta didik (klien), disabilitas memahami, menghayati, dan mengemalkan nilai dan norma tersebut; (10). keahlian, yaitu menghendaki agar layanan dan kegiatan bimbingan dan konseling diselenggarakan atas dasar kaidah-kaidah professional. Keprofesionalan guru pembimbing harus terwujud baik dalam penyelenggaraan jenis-jenis layanan dan kegiatan bimbingan dan konseling maupun dalam penegakan kode etik bimbingan dan konseling (11). Alih Tangan Kasus, yaitu menghendaki agar pihak-pihak yang tidak mampu menyelenggarakan layanan bimbingan dan konseling secara tepat dan tuntas atas suatu permasalahan peserta didik (klien) mengalihtangankan permasalahan itu kepada pihak yang lebih ahli. Guru pembimbing dapat menerima alih tangan kasus dari orangtua, guru-guru lain, atau ahli lain dan demikian pula guru pembimbing dapat mengalihtangankan kasus kepada guru mata pelajaran/praktik, kepada psikolog dan juga dokter jika diperlukan. (12) Azas Tut Wuri Handayani, yaitu asas bimbingan dan konseling yang menghendaki agar pelayanan bimbingan dan konseling secara keseluruhan dapat menciptakan suasana yang mengayomi (memberikan rasa nyaman), mengembang keteladanan, memberi rangsangan dan dorongan serta kesempatan seluas-luasnya kepada siswa secara umum dan siswa disabilitas.

Gibson, dan Marianne H.Mitcel (2010: 116) lebih fokus menjelaskan azas BK yang berasal dari konsep-konsep filosofis tentang kemanusiaan yang menjadi dasar bagi pemberian layanan bantuan atau bimbingan, baik di sekolah termasuk dalam Pendidikan inklusif. Prinsip-prinsip dimaksud adalah sebagai berikut: (1) Bimbingan diperuntukan bagi semua individu (guidance is for all individuals) Prinsip ini berarti bahwa bimbingan diberikan kepada semua individu atau peserta didik, baik yang tidak bermasalah maupun yang bermasalah. Apakah masalah itu kejiwaan atau disabilitas secara umum; baik pria maupun wanita; baik anak-anak, remaja maupun dewasa. Dalam hal ini pendekatan yang digunakan dalam bimbingan lebih bersifat preventif dan pengembangan dari pada penyembuhan; dan 
lebih diutamakan teknik kelompok daripada perseorangan (individual); (2) Bimbingan dalam Pendidikan inklusif lebih bersifat individualisasi. Setiap individu bersifat unik (berbeda satu sama lainnya sesuai dengan keterbatasannya masing-masing), dan melalui bimbingan individu dibantu untuk memaksimalkan perkembangan keunikannya tersebut. Prinsip ini juga berarti bahwa yang menjadi fokus sasaran bantuan adalah individu, meskipun layanan bimbingannya mengunakan teknik kelompok; (3). Bimbingan menekankan hal yang positif. Dalam kenyataan masih saja ada individu yang memiliki pemikiran negative terhadap siswa yang menyandang kekurangan atau disabilitas. Mestinya dengan bimbingan konselor berusaha memberikan dorongan dan peluang untuk berkembang sesuai dengan potensi yang dimiliki masing-masing klien; (4) Bimbingan merupakan usaha bersama. Bimbingan bukan hanya tugas atau tanggung jawab konselor, tetapi juga tugas guru-guru dan kepala sekolah. Mereka sebagai teamwork terlibat dalam proses bimbingan; (5) Pengambilan keputusan merupakan hal yang esensial dalam bimbingan. Bimbingan diarahkan untik membantu individu (juga anak berkebutuhan khusus) agar dapat melakukan pilihan dan mengambil keputusan. Kehidupan individu diarahkan oleh tujuannya, dan bimbingan memfasilitasi individu untuk mempertimbangkan, menyesuaikan diri, dan menyempurnakan tujuan melalui pengambilan keputusan yang tepat. Jones et.al (1970) berpendapat bahwa kemampuan untuk membuat pilihan secara tepat bukan kemampuan bawaan, tetapi kemampuann yang harus dikembangkan. Tujuan utama bimbingan adalah mengembangkan kemampuan individu untuk memecahkan masalahnya dan mengambil keputusan (6) Bimbingan berlangsung dalam berbagai setting kehidupan.

\section{PEMBAHASAN}

\section{Berbagai Masalah Anak Pendidikan Inklusif}

Manusia dilahirkan bertujuan untuk meneruskan generasi keturunan yang diharapkan dapat menjadi tumpuan kedua orang tua nantinya. Namun kenyataanya tidak semua manusia dilahirkan dengan kesempurnaan, diantaranya terdapat anak anak yang dilahirkan dengan keadaan memiliki hambatan, gangguan, dan kelainan. Masalah akan muncul ketika seseorang tidak menerima dan kecewa apa yang telah diberikan Tuhan kepadanya. Terdapat berbagai masalah yang umum dapat dialami oleh anak berkebutuhan khusus diantaranya, masalah perbedaan individu, masalah perkembangan individu, masalah kebutuhan individu, dan masalah penyesuaian diri. Kustawan (2013: 64) menyatakan terdapat berbagai masalah yang menyertai anak berkebutuhan khusus. Berikut akan dijabarkan mengenai intisari pendapat di atas tentang inti sari masalah anak berkebutuhan khusus; (1) Masalah Pribadi dan Penerimaan 
Diri. Setiap anak akan memiliki permasalahan yang berbeda satu sama lainnya. Dalam keadaan tertentu anak akan mengalami permasalahan yang besumberdari dalam dirinya sendiri. Kondisi semacam ini sangat mungkin terjadi pada anak berkebutuhan khusus yang secara nyata mereka memiliki kekurangan. Permasalahan pribadi dan penyesuaian diri ini muncul karena anak berkebutuhan khusus tidak berhasil menyesuaikan dan mengahadapi hal yang berkenaan dengan dirinya; (2) Masalah Penerimaaan Orang Tua (Keluarga). Semua orang tua mengharapkan bahwa anaknya kelak akan hidup dengan sukses dan mandiri, namun impian tersebut akan menjadi bumerang orang tua ketika mengetahui bahwa anaknya lahir dengan kekurangan kondisi fisik,mental,psikis, social, dan memiliki perilaku yang berbeda dengan anak pada umumnya (Maulyda, Sukoriyanto, et al., 2020). Jika orang tua dapat menerima dengan lapang dada anak bekebutuhan khusus mungkin permasalahan akan selesai di situ, namun jika orang tua tidak dapat menerima anaknya yang memiliki kebutuhan khusus akan menjadikan permasalahan bagi orang tua dan anak yang bersangkutan. Disini peran bimbingan dan konseling untuk melakukan pendekatan dengan keluaarga anak berkebutuhan khusus dijalankan agar nantinya keluarga dapat menerima dan mengurangi masalah pribadi dari anak berkebutuhan khusus; (3) Masalah Sosial dan Penerimaan Masyarakat. Acapkali anak berkebutuhan khusus akan menghadapi masalah lingkungan dan hubungan dengan orang lain di sekitarnya. Selain karena kurangnya interaksi dengan lingkungan, anak berkebutuhan khusus juga memiliki masalah dikarenakan hambatan yang ada di dirinya.Anak berkebutuhan khusus sering kali mengalami kesulitan untuk berinteraksi dan bermain dengan anak lainnya, hal ini menyebabkan anak berkebutuhan khusus minder dan merasa terasingkan dengan kehidupan sosial sekitar; (4) Masalah Belajar Permasalahan belajar anak berkebutuhan khusus ini sering kali berkaitan dengan alat bantu pembelajaran yang dilaksanakan dalam pembelajaran. Pihak sekolah kadang kekurangan fasilitas yang mendukung pembelajaran anak berkebutuhan khusus,selain itu anak berkebutuhan khusus mengalami kesulitan dalam gaya belajar dan pengerjaan tugas; (5) Masalah Pendidikan dan Lanjutan Studi Ketikan anak berkebutuhan khusus masuk pada sekolah tertentu, apakah itu pada satuan pendidikan khusus (SLB) atau sekolah umum dan kejuruan yang menyelenggarakan pendidikan inklusi acapkali disertai dengan berbagai kesulitan yang berhubungan dengan kegiatan pendidikan pada umumnya. Permasalahan yang mencuat adalahpenyesuaian diri, pemilihan ekstrakulikuler, dan memilih jurusan yang cocok pada keadaan dirinya. 6) Masalah Pekerjaan Bagi anak berkebutuhan khusus acapkali menjadi masalah berkenaan dengan pemilihan jenis pekerjaan yang cocok dengan dirinya. Permasalahan ini tentunya juga bersinggungan dengan harapan 
orang tua berkenaan dengan masa depan anak tersebut; (7) Masalah Penggunaan Waktu Luang Ketidakmampuan untuk memilih kegiatan yang bermanfaat ataukegiatan produktif bagi anak berkebutuhan khusus seringkali menjadi permasalahan. Kegiatan yang tidak produktif seperti melamun, begadang, dan merenung akan menjadi masalah yang lebih besar lagi apabila terus menerus dilakukan.

\section{Peran bimbingan konseling bagi penyelenggaraan pendidikan inklusif}

Dalam penyelenggaan Pendidikan inklusif, BK memiliki peran yang sangat strategis dalam mencapai target cita-cita perkembangan individu peserta didik. Pada pokoknya pembimbing memiliki pelayanan dasar bimbingan yang bertujuan membantu semua konseli (peserta didik) agar dapat mencapai tugas-tugas perkembangannya secara optimal. Dalam rangka mencapai tujuan tersebut, maka layanan bimbingan dan konseling Pendidikan inklusif dapat menyusun program bimbingan sebagaimana yang telah disampaikan Bruce Shertzer and Shelley C. Stone. (1981: 74) sebagai berikut:

a. Layanan Orientasi, merupakan kegiatan membantu peserta didik agar memahami dan menyesuaikan diri dengan lingkungan barunya, terutama lingkungan di mana mereka menempuh pendidikan. Orientasi bersifat informatif, sehingga teknik-teknik pemberian informasi dapat digunakan dalam layanan orientasi. Orientasi dapat dilaksanakan dengan pertemuan tatap muka dalam kelompok besar (beberapa kelas), diadakan pertemuan di aula misalnya) ataupun dalam setting kelas, sesuai dengan kebutuhan, dengan menggunakan teknik ceramah ataupun talk-show Informasi orientasi bisa juga disampaikan dalam bentuk tertulis melalui media on-line (webb) ataupun media cetak, seperti brosur, plamfet, liflet, atau media papan bimbingan. dan menyesuaikan diri dengan lingkungan barunya, terutama lingkungan di mana mereka menempuh pendidikan. Layanan orientasi dalam pendidikan inklusif, menggunakan teknik dan metode yang dapat diterima oleh semua siswa, bagi siswa yang berkebutuhan khusus menggunakan media yang dapat diterima oleh klien sesuai dengan kondisi klien (karakteristik yang dialami).

b. Layanan Informasi, merupakan pemberian informasi tentang berbagai hal yang terkait dengan bidang pribadi, sosial, belajar maupun karir, sesuai dengan kebutuhan, dalam rangka perkembangan optimal konseli. Penyampaian informasi dapat dilaksanakan secara langsung melalui pertemuan tatap muka maupun melalui media, seperti dalam melaksanakan layanan orientasi. Teknik dalam layanan orientasi dapat digunakan dalam layanan informasi, sesuai dengan karakteristik dan kebutuhan klien. Misalnya huruf brail, 
Witono, A.H. (2020). Peran Bimbingan Dan...

digunakan untuk tuna netra, audio sebagai media penyampaian informasi untuk tuna rungu dsb.

c. Dalam layanan informasi dan orientasi bisa dilakukan secara klasikan berupa bimbingan. Bimbingan Kelas/ Bimbingan Klasikal, merupakan layanan bimbingan yang diberikan kepada semua konseli, termasuk anak yang berkebutuan khusus dalam seting kelas. Layanan dilaksanakan dalam bentuk tatap muka dan terjadwal secara rutin di setiap kelas dalam perminggu. Layanan Bimbingan dan Konseling diselenggarakan secara terprogram berdasarkan asesmen kebutuhan (need assessment) yang dianggap penting (skala prioritas) dilaksanakan secara rutin dan berkelanjutan(scaffolding). Teknik-teknik bimbingan kelompok dapat digunakan dalam layanan bimbingan klasikal, seperti teknik ekspositori, diskusi kelompok, diskusi kelas, teknik permainan simulasi, bermain peran dan sebagainya. Yang jelas dalam bimbingan klasikal ini tetap mempertimbangkan keberadaan peserta didik. Dalam pelaksanaannya diatur sesuai dengan potensi peserta didik, menyesuaikan dengan tingkat kemampuan dan potensi individu yang dibimbing. Artinya, karena di kelas itu ada siswa yang memiliki keterbatasan (disabilitas) maka konselor tidak bisa bekerja sendiri tetapi perlu ada tenaga lain yang membantunya, misalnya guru yang biasa sehari-hari membelajarkan siswa. Selain bimbingan klasikal, juga bisal dilaksanakan dengan bimbingan Kelompok, merupakan pelayanan bimbingan yang diberikan kepada konseli, dikelola dalam kelompok-kelompok kecil (anggota kelompok antara 5 - 10 orang). Layanan ini dimaksudkan untuk merespon kebutuhan dan minat sekelompok konseli atas materi-materi tertentu dalam rangka pencapaian tugastugas perkembangannya. Topik yang diangkat dalam bimbingan kelompok merupakan topik yang sifatnya umum, di bidang pribadi, sosial, belajar maupun karier, misalnya Latihan Memahami Diri dan Memahami Orang Lain, Keterampilan dalam Berkomunikasi Antar Pribadi, Kiat Sukses Menghadapi Ujian, Pengenalan Studi Lanjut dan Persiapan Pilihan Karier. Teknik atau yang melibatkan dinamika kelompok dan berfokus pada aktivitas konseli, biasanya menjadi teknik yang menarik dalam bimbingan kelompok, seperti diskusi kelompok dengan berbagai macam variasinya, bermain peranan, permainan simulasi, permainan kelompok, cinema edukasi dan lain sebagainya. paling sesuai dengan karakteristik dan masalah konseli. Bagi siswa berkebutuhan khusus, harus menggunakan media dan teknik yang bisa diterima dan dilakukan mereka, pada prinsipnya dalam penyelenggaraan bimbingan disesuaikan kemampuan yang ada. 
d. Layanan Pengumpulan Data (Aplikasi Instrumentasi), merupakan aktivitas mengumpulkan data atau informasi tentang diri konseli dan lingkungannya. Data ini diperlukan dalam rangka mengenali kebutuhan dan memahami diri pribadi konseli, yang dapat digunakan sebagai dasar dalam mengembangkan program pelayanan dasar. Data dikumpulkan dengan berbagai variasi instrumen, baik teknik tes maupun non tes.Dalam hal ini Nida Smith, A.Hari Witono, Fachruddin. (2019: 19) menyarankan bahwa pengumpulan data sangat diperlukan sebagai bentuk usaha sekolah, pembimbing untuk: Pertama, mengidentifikasi potensi awal siswa (dilihat dari sisi normalitas psikologis klien); kedua untuk menemukan dan menggolongkan siswa termasuk siswa yang berkebutuhan khusus sesuai dengan bakat dan minatnya. Atas dasar potensi yang telah ditemukan tersebut, maka Bk bisa menempatkannya sesuai dengan bidang-bidang dan karakteristik masing-masing peserta didik. Dengan demikian siswa akan merasa betah dan merasa memperoleh layanan sesuai dengan kebutuhan dan tingkat keterbatasan yang dialaminya.

e. Konseling Individual dan Konseling Kelompok, melalui konseling baik individual maupun kelompok sesuai dengan kebutuhan, konseli dibantu untuk mengidentifikasi masalah yang sedang dialami hingga dapat menemukan solusi yang tepat untuk memecahkan masalahnya. Berbagai model dan teknik dalam konseling dapat digunakan oleh konselor. Konselor dapat memilih model mana yang dikuasasi. Layanan konseling ini sangat dibutuhkan oleh klien, terutama siswa yang berkebutuhan khsus. Mengingat masalahmasalah yang dihadapi cukup banyak dan variative, sebagaimana diuraikan dalam butir D. Dengan layanan konseling individual diharapkan klien yang bermasalah dapat menemukan jawaban, dan jalan keluar yang dihadapi sehingga klien (termasuk siswa yang berkebutuhan khsusu) anak dapat berkembang optimal (aspek pribadi, social, dan kemampuan belajarnya) seirama dengan perkembangan siswa normal di kelas yang diikuti.

f. Konsultasi, layanan konsultasi dilaksanakan konselor dalam rangka memberikan bantuan kepada konseli. Konsultasi ditujukan kepada pihak-pihak yang mungkin terkait dengan upaya pemecahan masalah konseli, seperti konsultasi dengan guru bidang studi atau wali kelas, orang tua siswa, kepala sekolah. Melalui mekanisme konsultasi diharapkan bisa membangun kesamaan persepsi atas kasus konseli, yang bisa berlanjut dengan berkolaborasi dalam bantuan pemecahan masalah konseli. Bagi klien yang berkebutuhan khusus, banyak masalah yang dihadapi oleh pihak-pihak yang menanganinya, misalnya 
oranr tua. Jika swaktu-waktu orang tua kesulitan memberi perhatian kepada anak-anaknya yang memiliki kebutuhan khusus bisa melakukan konsultasi kepada guru BK di sekolah.

g. Referal, merupakan layanan yang diberikan kepada konseli dengan cara mengalih tangankan atau mengirim konseli kepada pihak lain yang lebih berkompeten. Tindakan referal merupakan tindak lanjut dari hasil penanganan kasus konseli melalui konseling, di mana menurut hasil evaluasi konselor, kasus yang dialami konseli sudah diluar kewenangan dan kompetensi konselor. Kasus yang direferal misalnya konseli yang mengalami depresi, kecanduan zat adiktif, sakit kronis, kesulitan belajar pada bidang studi tertentu dan atau memiliki cacat mental yang tidak bisa ditangani konselor sekolah. Pihak yang bisa menerima referal, sesuai dengan kasus dan jenis masalah klien. Misalnya klien yang mengalami kelainan mental akan direferal ke psikiater. Klien yang mengalami gangguan kesehatan akan diferal ke dokter, dst. Secata teknis, apabila referal ditujukan pada pihak di luar sekolah, maka mekanisme referal secara administratif hendaknya diketahui Kepala Sekolah.

\section{Manajemen Program BK dalam pendidikan inklusif}

Program bimbingan dan konseling dikelola/ di menej sebagai bagian yang integral dengan seluruh program Pendidikan inklusif. Menurut Knezevich (Ali Imron, 2011: 6), manajemen peserta didik atau pupil personnel administration merupakan suatu layanan yang memusatkan perhatian pada pengaturan, pengawasan dan layanan peserta didik di kelas ataupun di luar kelas seperti: pengenalan, pendaftaran, layanan individu seperti pengembangan kemampuan, minat, kebutuhan sampai peserta didik matang di sekolah.

Pengaturan terhadap peserta didik dilakukan untuk memberikan pelayanan yang sebaik mungkin kepada peserta didik termasuk peserta didik yang berkebutuhan khusus dalam penyelenggaraan pendidikan inklusif, sehingga setiap peserta didik mendapatkan pelayanan pendidikan yang layak tanpa adanya diskriminasi.

Sistem pendidikan inklusif memiliki arti bahwa sekolah harus mampu menyiapkan dan menyelenggarakan pelayanan terhadap anak tanpa memandang kondisi fisik, kecerdasan, sosial emosional, linguistik atau kondisi lainnya (Tarmansyah, 2007: 82). Hal tersebut berarti sekolah inklusif memberikan pelayanan belajar dan mengajar dan juga bimbingan konseling pada anak-anak berkebutuhan khusus bersama dengan anak normal pada umumnya, sehingga mereka dapat menyesuaikan diri dengan kehidupan sehari-hari. Misalnya selama ini tamatan dari SLB tidak mudah diterima oleh lingkungan masyarakat, hal tersebut dikarenakan ABK terpisah dan kurang bersosialisasi dengan lingkungan masyarakat. Keberadaan sekolah 
inklusif, di dalamnya ada layanan BK diharapkan dapat memberikan kesempatan sebesarbesarnya terhadap anak berkebutuhan khusus untuk belajar di sekolah-sekolah reguler yang ditunjuk sebagai sekolah inklusif, sehingga ABK dapat bersosialisasi dengan baik dan lebih dapat diterima oleh lingkungan masyarakat. Terkait dengan hal tersebut diharapkan upaya semua pihak yang terkait dengan sekolah (guru, konselor, kepala sekolah dan tenaga Pendidikan, dan bahkan komite sekolah) dapat berkordinasi memberikan pelayanan yang maksimal kepada peserta didik yang secara organisatoris diatur kepala sekolah. Semua itu dilakukan untuk dapat mewujudkan pelayanan pendidikan tanpa membeda-bedakan fisik, kecerdasan, sosial emosional, linguistik atau kondisi lainnya.

Berdasarkan pedoman umum penyelenggaraan pendidikan inklusif Departemen Pendidikan Nasional Direktorat Jendral MANDIKDASMEN Direktorat Pembinaan Sekolah Luar Biasa (2007) dalam mekanisme penyelenggaraan pendidikan inklusif, calon sekolah penyelenggara Pendidikan inklusif harus memenuhi kriteria sebagai berikut meliputi: “1) Kesiapan sekolah untuk menyelenggarakan program pendidikan inklusif (kepala sekolah, komite sekolah, guru, peserta didik, dan orang tua); 2) Terdapat anak berkebutuhan khusus di lingkungan sekolah; 3) Tersedia Guru Pembimbing Khusus, atau di dalam hal ini disebut guru pembimbing atau konselor sekolah (guru tetap sekolah atau guru yang diperbantukan dari lembaga lain); 4) Komitmen terhadap penuntasan wajib belajar; 5) Memiliki jaringan kerjasama dengan lembaga lain yang relevan; 6) Tersedia sarana penunjang yang mudah diakses oleh semua anak; 7) Pihak sekolah telah memperoleh sosialisasi tentang pendidikan inklusif; 8) Sekolah tersebut telah terakreditasi; 9) Memenuhi prosedur administrasi yang telah ditentukan." Berdasarkan pedoman di atas menunjukkan bahwa dalam menyelenggarakan pendidikan inklusif, sekolah harus memenuhi kriteria seperti yang telah dijelaskan di atas.

\section{Tantangan implementasi BK dalam Pendidikan Inklusif}

Seiring dengan keberadaan Pendidikan inklusif di Indonesia kini yang belum mapan saat ini (Nida Smith, A. Hari Witono, Fachruddin. 2019, 7) maka ada sejumlah tantangan Bimbingan Konseling dalam penyelenggaraannya di sekolah-sekolah model inklusif, antara lain:

a. Belum ada pola baku tentang pelaksanaan BK di sekolah inklusif, hal itu terungkap sebagaimana dinyatakan Prayitno, 2009: 16 yang menyatakan bahwa BK di Indonesia kini terus dilakukan penataan. Antara lain, dari pola tidak jelas kea rah Bimbingan konseling pola 17.

b. Belum ada tenaga ahli, konselor professional yang secara khusus menangani anak di dalam Pendidikan inklusif. Hal ini, terbukti dari belum adanya penyiapan tenaga guru 
pembimbing, konselor sekolah dari LPTK di Indonesia atau Perguruan Tinggi penghasil lulusan Bimbingan Konseling. Juga belum adanya penempatan secara resmi Guru BK (sebagaimana di SLTP dan SLTA pada umumnya yang telah ada petugas BKnya) di sekolah model inklusif.

c. Banyak siswa yang berkebutuhan khusus yang membutuhkan penanganan bimbingan dan konseling yang intensif, berdasarkan bakat, minat dan potensi-potensiyang dimiliki. Badan Pusat Statistik (BPS) 2017 menyebutkan bahwa jumlah anak berkebutuhan khusus (ABK) di Indonesia adalah sebanyak 1,6 juta orang. Artinya, satu juta lebih ABK belum memperoleh pendidikan yang penting bagi kehidupannya. Dari 30\% ABK yang sudah memperoleh pendidikan, hanya $18 \%$ di antaranya yang menerima pendidiikan inklusi, baik dari sekolah luar biasa (SLB), maupun sekolah biasa pelaksana pendidikan inklusif.

\section{SIMPULAN}

Bimbingan dan konseling dalam Pendidikan inklusif sebagai bagian yang integral dalam system Pendidikan di Indonesia. Tujuan BK adalah seirama dan seiring dengan tujuan Pendidikan di Indonesia sebagaimana diamanakan dalam Undang-undang system Pendidikan Nasional (USPN) Republik Indonesia. Keberadaan BK di system Pendidikan inklusif menjadi sebuah kekuatan, dari kekuatan potensi rekayasa pendidikan lainnya (aspek administrasi-manajemen dan pembelajaran). Ketiganya menjadi kekuatan yang utuh dalam pencapaian tujuan Pendidikan tersebut.

Di dalam pelaksanaan Pendidikan inklusif BK memiliki peran yang sangat strategis, antara lain; Pertama, mengumpulkan data (appraisal); yaitu untuk menemu kenali potensipotensi peserta didik, mana yang berkebutuhan khusus dan juga untuk menemukan potensi bakat dan minat secara umum; Kedua, orientasi (orientation), yaitu untuk memberi bekal pengenalan lingkungan, maupun potensi diri peserta didik. Tujuan utamanya ialah agar memahami diri dan lingkungannya; Ketiga, informasi (information) ialah memberi berbagai bahan informasi, tentang belajar, pribadi, social dan karir. Pemberian informasi ini hendaknya menggunakan alat dan teknik dan bahkan media yang bisa dilakukan dan diterima oleh klien dalam Pendidikan inklusif. Bentuk pelaksanaanya bisa berupa bimbingan individual maupun kelompok. Keempat, Konseling (counseling). Peran ini sangat urgen sifatnya bagi peserta didik yang mengalami masalah. Mengingat layanan konseling diberikan lebih bersifat individual, dan kuratiff. Mengingat banyaknya masalah pribadi peserta didik (klien) dalam Pendidikan inklusif konseling (face to face relationship) sangat cocok diberikan. Kelima, konsultasi 
Witono, A.H. (2020). Peran Bimbingan Dan...

(consultation). Tidak sedikit berbagai pihak yang berhubungan dengan anak yang berkebutuhan khusus menemui masalah dalam memberi perhatian educative. Jika menemui kesulitan macam itu, maka pihak-pihak tersebut diberi keleluasaan untuk minta layanan konsultasi kepada petugas BK, guru BK di sekolah. Keenam, Referal. Langkah ini dilakukan oleh guru BK di sekolah, jika sewaktu-waktu dalam pelayanannya kepada klien menunjukkan tidak ada hasil. Hal itu lebih banyak disebabkan oleh keterbatasan kewenangan. Maka sebagai langkah terakhir guru BK mengalihtangankan (referal) kepada pihak terkait, atas persetujuan klien yang dibimbingnya.

BK di sekolah inklusif masih banyak menghadapi hambatan dan tantangan. Tantangan dimaksud ialah seiring dengan pelaksanaan Pendidikan Inklusif di Indonesia sampai saat ini yang belum mapan.

\section{DAFTAR PUSTAKA}

Ahmad Nawawi.2019. Pendidikan Inklusif. Jurusan Pendidikan Luar Biasa Fakutas Ilmu Pendidikan UPI Bandung.

Bruce Shertzer and Shelley C. Stone. 1981. Fundamentals of Guidance. Publisher: Houghton Mifflin.

Hidayati, V. R., Wulandari, N. P., Maulyda, M. A., Erfan, M., \& Rosyidah, A. N. K. (2020). Literasi Matematika Calon Guru Sekolah Dasar dalam Menyelesaikan Masalah PISA Konten Shape \& Space. JPMI: Jurnal Pembelajaran Matematika Inovatif, 3(3), 1-10.

Kustawan, D. 2013. Bimbingan dan Konseling Bagi Anak Berkebutuhan Khusus. Jakarta: Luxima Metro Media

Lay Kekeh Marthan. (2007). Manajemen Pendidikan Inklusif. Jakarta: DIRJEN DIKTI.

Nida Smith, A. Hari Witono, Fachruddin. 2019. Implementasi Program Pendidikan Inklusif(di SMP negeri 4 Praya Kabupaten Lombok Tengah. Mataram University Press.

Maulyda, M. A., Nurmawanti, I., \& Khair, M. S. (2020). Deskripsi Kemampuan Koneksi Matematis Siswa Kelas X Pada Materi Sistem Persamaan Linear Tiga Variabel. SJME (Supremum Journal of Mathematics Education), 4(1), 1. https://doi.org/10.35706/sjme.v4i1.2026

Maulyda, M. A., Sukoriyanto, S., Hidayati, V. R., Erfan, M., \& Umar, U. (2020). Student Representation in Solving Story Problems Using Polya Steps. Formatif: Jurnal Ilmiah Pendidikan MIPA, 10(1), 25-34. https://doi.org/10.30998/formatif.v10i1.4629 
Witono, A.H. (2020). Peran Bimbingan Dan...

McLeod. 2006. An Introduction to Counseling. Pengantar Konseling: Teori dan Studi kasus. Alih Bahasa A.K. Anwar. Jakarta. Fajar Interprataa.

Munawir Yusuf, Abdul Salim, Sugini, Dewi Sri Rejeki, Imam Subkhan. 2018. Pendidikan Inklusif dan Pendidikan Anak. Solo. Penerbit Tiga Serangkai.

Gibson, Robert, Marianne H. Mitchell. Alih Bahasa Yudi Santoso. 2010. Bimbingan dan Konseling. Edisi Ketujuh. Yogyakarta. Pustaka Pelajar.

Peraturan Menteri Pendidikan dan Kebudayaan Nomor 111 tahun 2014 tentang Bimbingan dan Konseling pada Pendidikan Dasar dan Menengah. Jakarta: Kemendikbud RI.

Ramli, M. Nurhidayah, Elia Flurentin, Ella Faridatin Zen.Blasius Boli Lasan, dan Imam Hambali. 2017. Sumber Belajar Penunjang Plpg 2017. Mata Pelajaran/Paket Keahlian Bimbingan Dan Konseling. Kementerian Pendidikan Dan Kebudayaan Direktorat Jenderal Guru Dan Tenaga Kependidikan.

Sue Stubbs, alih bahasa Susi Septaviana, R. Diedit oleh: Didi Tarsidi. 2002. Pendidikan Inklusif (Ketika hanya ada sedikit sumber). The Atlas Alliance. Jurusan Pendidikan Luar Biasa, UPI Bandun

Prayitno, Erman Amti. 2016. Dasar-dasar bimbingan dan konseling. Jakarta. Pusat Perbukuan, Depdiknas.

Van Zandt, Jo Hayslip.2001. Developing Your School Counseling Program. A Handbook for Systemic Planning. USA. Wadsworth/Thomson Learning -Belmont, CA.,

UNESCO (1994). The Salamanca Statement and Framework for Action on 4th Edition. New York: McGraw - Hill Companies 